\title{
PENGARUH PEMBERIAN ABU SEKAM SEBAGAI SUMBER SILIKA (SI) BAGI PERTUMBUHAN DAN PRODUKSI TANAMAN PADI (Oriza sativa 1.)
}

\author{
Teguh Budi Prasetyo, Irwan Darfis, Rahmi Fitri \\ J urusan Tanah F akultas Pertanian U niversitas Andalas
}

\begin{abstract}
This research was conducted in greenhouse at Agriculture Faculty of Andalas University from August 2006 to February 2007. The objective of the research was to study the effect of fly ash as silicon ( $\mathrm{Si}$ ) resource for plant growth and rice production. The experiment was designed on Completely Randomized Block Design in four treatments and three replicates. The treatments consisted of without fly ash, $1400 \mathrm{~kg} / \mathrm{ha}, 2800 \mathrm{~kg} / \mathrm{ha}$ and $5600 \mathrm{~kg} / \mathrm{ha}$ fly ash. The results showed that fly ash could increase available fosfor, silica, cations and reduce Aluminium of the soil. Fly ash could also increase production and absorbtion of fosfor and plant silicon.
\end{abstract}

Key words: Fly ash, silicon, and rice production

\section{PENDAHULUAN}

Kebutuhan pangan yang terus meningkat seiring dengan perkembangan penduduk tanpa diikuti oleh peningkatan produksi pertanian akan menyebabkan kesenjangan yang makin jelas antara konsumsi dan hasil produksi. Salah satu cara untuk meningkatkan produksi yaitu dengan intensifikasi pertanian. Intensifikasi adalah dengan cara peningkatan hasil produksi dengan jalan mempertinggi produktivitas.

Dilain pihak Taher dan Abbas (1990) mengungkapkan bahwa dengan pertumbuhan penduduk yang sangat tinggi mengharuskan Indonesia untuk meningkatkan produksi padi karena sebagian besar penduduk Indonesia mengkonsumsi beras sebagai makanan pokoknya. Beberapa tahun yang lalu pulau Jawa merupakan produsen pangan terbesar di Indonesia yaitu lebih kurang $60 \%$.

Sebagai unsur hara essensial, $\mathrm{Si}$ luput dari perhatian pemerintah dan para petani sawah. Ini terbukti dengan tidak adanya penambahan $\mathrm{Si}$ secara artifisial dalam praktek bercocok tanam padi selama ini. Perpindahan Si keluar areal persawahan melalui proses pemanenan dan pencucian tanpa diiringi dengan penambahan Si secara artifisial diduga merupakan faktor utama dalam proses penurunan kandungan $\mathrm{Si}$ tersedia dalam tanah (Otsuka, 2000 dan Kyuma, 2004 cit Darmawan, 2005).

Salah satu sumber $\mathrm{Si}$ yang dapat dimanfaatkan adalah abu sekam padi. Sekam padi merupakan salah satu hasil buangan dari proses penggilingan padi. Hasil buangan ini kerap kali menimbulkan masalah dalam pengolahannya. Pada lokasi penggilingan padi, sekam hanya ditimbun dan dibiarkan menumpuk menjadi bukitbukit kecil. Di Indonesia, sekam telah dimanfaatkan untuk alas kandang dan bahan bakar untuk pembakaran bata (Winarno, 1985). Berdasarkan hasil penelitian Sigit ( 1984, cit Azhari, 1992), abu sekam mengandung unsur hara dengan komposisi sebagai berikut , $0,15 \%$ Nitrigen $(\mathrm{N})$, $0,16 \%$ Fosfor (P), 1,85 \% Kalium (K), $0,49 \%$ Kalsium (Ca), 1,05 \% Magnesium (Mg), 0,4 \% C-organik dan 68,7 \% $\mathrm{SiO}_{2}$.

Penelitian ini bertujuan untuk mempelajari pengaruh pemberian takaran abu sekam sebagai sumber silika serta untuk mendapatkan takaran optimal untuk pertumbuhan dan produksi tanaman padi (Oriza sativa L.)

\section{BAHAN DAN METODA}

Contoh Tanah

Tanah sawah yang digunakan untuk penelitian ini berasal dari tanah sawah daerah Sirukam Kec. Payung Sekaki Kab. 
Solok. Sebagai tanaman indikator digunakan tanaman varietas anak daro. Penelitian ini berbentuk percobaan pot di rumah kaca yang disusun menurut Rancangan Acak Lengkap (RAL) dengan 4 perlakuan dan 3 ulangan. Adapun perlakuan abu sekam yang diberikan : A) tanpa abu sekam, B) $1400 \mathrm{~kg} / \mathrm{ha}(5,6 \mathrm{~g} / \mathrm{pot})$, C) 2800 $\mathrm{kg} / \mathrm{ha}(11.2 \mathrm{~g} / \mathrm{pot})$, dan D) $5600 \mathrm{~kg} / \mathrm{ha}(22,4$ g/pot). Sampel tanah diambil secara komposit pada kedalaman $0-20 \mathrm{~cm}$. Sampel tanah yang telah dikeringanginkan, kemudian diayak dengan ayakan $2 \mathrm{~mm}$. sampel tanah yang telah diayak dimasukkan ke dalam pot dengan berat $8 \mathrm{~kg} /$ pot setara dengan berat kering mutlak dengan jumlah pot percobaan 12 buah. Sampel tanah diambil $200 \mathrm{~g}$ untuk analisis sifat kimia tanah awal. Analisis tanah yang dilakukan yaitu analisis tanah awal dan setelah inkubasi meliputi penetapan $\mathrm{pH}_{2} \mathrm{O}(1: 1)$ yang diukur dengan $\mathrm{pH}$ meter, Al-dd, penetapan P-tersedia dengan metoda Bray II, penetapan Si-tersedia dengan metoda buffer asetat dan penetapan kation-kation basa $(\mathrm{K}$, $\mathrm{Ca}, \mathrm{Mg}$ dan $\mathrm{Ca}-\mathrm{dd})$ dengan metoda pencucian Amonium Asetat $1 \underline{\mathrm{N}} \mathrm{pH} 7$.

Contoh Tanaman

Tabel 1. Hasil analisis tanah awal beberapa sifat kimia Oxisol

\begin{tabular}{|c|c|c|}
\hline Jenis Analisis & Nilai & Kriteria * \\
\hline $\mathrm{pH} \mathrm{H} \mathrm{H}_{2} \mathrm{O}$ & 4.56 & Masam \\
\hline $\mathrm{pH} \mathrm{KCl}$ & 3.72 & - \\
\hline P_tersedia (ppm) & 36.73 & Sedang \\
\hline Si_tersedia ppm) & 21,21 & Sgt kurang $* *$ \\
\hline Ca_dd (me/100g) & 3,38 & Rendah \\
\hline Mg_dd (me/100g) & 0,86 & Rendah \\
\hline K_dd (me/100g) & 0,52 & Sedang \\
\hline Na_dd (me/100g) & 0.66 & Sedang \\
\hline Al_dd (me/100g) & 4,09 & - \\
\hline Kej. $\mathrm{Al}(\%)$ & 44.51 & Tinggi \\
\hline
\end{tabular}

Sumber : * LPT Bogor (1983, cit Hardjowigeno 2003)
Analisis tanaman yang dilakukan meliputi pengamatan tinggi tanaman, jumlah anakan produktif, berat kering gabah dan serapan P serta Si tanaman.

\section{HASIL DAN PEMBAHASAN}

Analisis Tanah Awal

Analisis tanah awal meliputi $\mathrm{pH}, \mathrm{P}$ tersedia, Si-tersedia dan basa-basa yang dapat dipertukarkan. Hasil analisis ciri kimia contoh tanah di laboratorium disajikan pada Tabel 1.

Berdasarkan hasil analisis tanah awal dapat dilihat bahwa tanah yang digunakan untuk penelitian ini menunjukkan $\mathrm{pH}$ yang sangat rendah, kandungan $\mathrm{P}$ tersedia berada pada kriteria sedang, kandungan basa-basa yang dapat dipertukarkan berada pada kriteria rendah serta Si-tersedia berada pada kriteria sangat kurang. Akan tetapi tanah ini memiliki kejenuhan $\mathrm{Al}$ yang tinggi yang dapat meracun tanaman.

Tanah ini bereaksi masam dengan nilai $\mathrm{pH} \mathrm{H2O}$ sebesar 4.56. Menurut Hakim et al (1986) bahwa reaksi tanah yang sangat

\footnotetext{
** Selected method for soil and plant analisys manual series No 1 ( cit Balitan Sukarami, 1990)
} 
masam ini disebabkan oleh adanya ion $\mathrm{Al}+3$ pada kompleks jerapan yang mudah dihidrolisis dan menghasilkan ion $\mathrm{H}^{+}$yang memberikan nilai $\mathrm{pH}$ rendah dan merupakan penyebab kemasaman pada tanah.

Secara keseluruhan dapat dikatakan bahwa tanah ini mempunyai tingkat kesuburan yang rendah. Menurut Soepardi (1983), tanah masam dicirikan dengan rendahnya kation-kation basa, serta meningkatnya unsur $\mathrm{Al}$, $\mathrm{Fe}$ dan $\mathrm{Mn}$. Keadaan ini dapat mengganggu serapan hara tanaman dan dapat mengurangi produksi tanaman, oleh karena itu diperlukan usaha untuk meningkatkan unsur hara tanah, yang akhirnya akan meningkatkan serapan hara dan produksi tanaman padi.

\section{Analisis Tanah Setelah Inkubasi}

Berdasarkan penelitian yang telah dilakukan hasil analisis terhadap ciri kimia setelah diinkubasi dengan abu sekam sebagai sumber Silika (Si) dapat dilihat pada Tabel 2.

Dari Tabel 2 di atas terlihat bahwa berdasarkan kriteria penilaian sifat kimia tanah terlihat bahwa adanya kecenderungan meningkatnya $\mathrm{pH}$ tanah, tetapi masih relatif kecil dan masih berada pada kriteria sedang. Peningkatan $\mathrm{pH} \quad \mathrm{H}_{2} \mathrm{O}$ tanah ini disebabkan oleh kation-kation basa yang terdapat pada abu sekam. Dimana basa-basa dari abu sekam tersebut dapat menetralkan kemasaman tanah atau menurunkan ion $\mathrm{H}^{+}$ sehingga $\mathrm{pH} \mathrm{H}_{2} \mathrm{O}$ tanah menjadi meningkat. Menurut Sarief (1985), pelepasan kationkation basa ke dalam tanah menyebabkan ion $\mathrm{H}^{+}$dalam larutan tanah yang dapat berperan dalam peningkatan kemasaman tanah dapat dipertukarkan dengan basa-basa yang dibebaskan sebagai hasil dekomposisi dalam tanah dapat meningkatkan $\mathrm{pH}$.

P-tersedia meningkat dari kriteria rendah menjadi tinggi dengan pemberian abu sekam $1400 \mathrm{~kg} / \mathrm{ha}$, meningkatnya Ptersedia sebesar 4,34 satuan dibandingkan tanpa pemberian abu sekam. Sedangkan pemberian abu sekam sebanyak $2800 \mathrm{~kg} / \mathrm{ha}$ meningkatkan P-tersedia menjadi 42,49 ppm P. Pada perlakuan $5600 \mathrm{~kg} / \mathrm{ha}$ P-tersedia meningkat menjadi 44,77 ppm P

Tabel 2. Hasil analisis sifat dan ciri kimia tanah setelah diinkubasi dengan abu sekam sebagai sumber Silika ( $\mathrm{Si}$ ) terhadap $\mathrm{pH} \mathrm{H}_{2} \mathrm{O}, \mathrm{P}$-tersedia, Si-tersedia, kation-kation basa dan kejenuhan $\mathrm{Al}$

\begin{tabular}{ccccc}
\hline Jenis analisis & $\begin{array}{c}\text { Tanpa abu } \\
\text { sekam }\end{array}$ & $\begin{array}{c}1400 \\
\mathrm{~kg} / \mathrm{ha}\end{array}$ & $\begin{array}{c}2800 \\
\mathrm{~kg} / \mathrm{ha}\end{array}$ & $5600 \mathrm{~kg} / \mathrm{ha}$ \\
\hline $\mathrm{pH} \mathrm{H} \mathrm{H}_{2} \mathrm{O}$ & $4,59 \mathrm{~m}$ & $4,69 \mathrm{~m}$ & $4,85 \mathrm{~m}$ & $5,45 \mathrm{~m}$ \\
P-tsedia & $36,59 \mathrm{~s}$ & $40,93 \mathrm{t}$ & $42,49 \mathrm{t}$ & $44,77 \mathrm{t}$ \\
Si-tsedia & $22,84 \mathrm{sk}$ & $50,81 \mathrm{k}$ & $62,57 \mathrm{k}$ & $67,49 \mathrm{k}$ \\
K-dd & $0,52 \mathrm{~s}$ & $0,56 \mathrm{~s}$ & $0,60 \mathrm{t}$ & $0,62 \mathrm{t}$ \\
Na-dd & $0,52 \mathrm{~s}$ & $0,67 \mathrm{~s}$ & $0,84 \mathrm{t}$ & $0,95 \mathrm{t}$ \\
Ca-dd & $3,22 \mathrm{r}$ & $3,38 \mathrm{r}$ & $3,42 \mathrm{r}$ & $3,52 \mathrm{r}$ \\
Mg-dd & $0,83 \mathrm{r}$ & $0,84 \mathrm{r}$ & $0,84 \mathrm{r}$ & $0,84 \mathrm{r}$ \\
Al-dd & 4,05 & 3,51 & 2,62 & 2,25 \\
Kej. Al & $39,97 \mathrm{t}$ & $35,21 \mathrm{t}$ & $26,93 \mathrm{~s}$ & $24,49 \mathrm{~s}$ \\
\hline
\end{tabular}

Sumber : * LPT Bogor (1983, cit Hardjowigeno 2003)

Keterangan : $\mathrm{sm}=$ sangat masam $\mathrm{r}=$ rendah

$$
\mathrm{s}=\text { sedang } \mathrm{t}=\text { tinggi } \mathrm{sk}=\text { sangat kurang } \mathrm{k}=\text { kurang }
$$


atau meningkat sebesar 2,28 satuan dari perlakuan $2800 \mathrm{~kg} / \mathrm{ha}$ yaitu $42,49 \mathrm{ppm} \mathrm{P}$. Akan tetapi peningkatan P-tersedia setelah diberikan abu sekam tetap berada pada kriteria tinggi.

Meningkatnya P-tersedia karena pemberian abu sekam sebgai sumber $\mathrm{Si}$ dapat mengurangi sorpsi $\mathrm{P}$ oleh komponen tanah. Sorpsi $\mathrm{P}$ berkurang karena Silikat mampu membebaskan $\mathrm{P}$ yang disorpsi oleh komponen tanah melalui pertukaran anion antara P dengan Si. Wiralaga, Lubis, Pulung, Hakim, dan Nyakpa (1988), menyatakan bahwa, anion silikat dapat digunakan untuk mengurangi sorpsi $\mathrm{P}$ pada tanah. Hal ini sesuai dengan yang dikemukan oleh Soepardi (1983), dimana pemberian silikat dapat meningkatkan kadar P tanah menjadi bentuk lebih tersedia bagi tanaman.

Dari penelitian Salehuddin (1990) didapatkan bahwa bertambahnya P-tersedia ini disebabkan oleh pelepasan $\mathrm{P}$ pada proses dekomposisi sekam dan juga sebagai akibat adanya sumbangan $\mathrm{SiO}_{2}$ dari abu sekam. Silikat mempunyai kemampuan meningkatkan ketersedian tanah. Wiralaga et al (1988) menyatakan bahwa, anion silikat dapat mengurangi fiksasi melalui proses pertukaran. Sanchez (1992) menambahkan bahwa terjadinya peningkatan ketersediaan $\mathrm{P}$ disebabkan oleh proses pertukaran anion di kompleks jerapan.

Pada waktu pemberian $1400 \mathrm{~kg} / \mathrm{ha}$, Si-tersedia meningkat 27,97 satuan sedangkan pada waktu pemberian 2800 $\mathrm{kg} / \mathrm{ha}$, Si-tersedia meningkat 39,73 satuan dan dengan pemberian $5600 \mathrm{~kg} / \mathrm{ha} \mathrm{Si}$ tersedia meningkat 44,65 satuan bila dibadingkan dengan tanpa pemberian perlakuan abu sekam. Walaupun Si-tersedia meningkat namun berada pada kriteria kurang.

Abu sekam sebagai sumber Si dapat meningkatkan kandungan Si-tersedia (ppm) pada tanah sawah. Dimana semakin besar dosis perlakuan abu sekam yang diberikan maka semakin tinggi kandungan Si-tersedia di dalam tanah. Menurut penelitian Hermansyah (1993), semakin banyak Si diberikan maka sebagian $\mathrm{Si}$ akan terjerap pada tapak jerapan dan sebagian akan tetap larut dalam larutan tanah.

Terjadinya peningkatan kandungan K-dd tanah setelah inkubasi, disebabkan karena sumbangan hara yang berasal dari abu sekam. Seiring dengan pendapat Ismunadji, Satari dan Muljadi (1989) pengembalian residu tanaman padi melalui proses pembakaran dapat menyumbangkan hara untuk tanaman terutama sekali unsur hara K.

Meningkatnya kandungan kationkation basa dalam tanah disebabkan karena pemberian abu sekam yang nantinya akan menyumbangkan kation-kation basa yang terdapat di dalam abu sekam akan disumbangkan ke dalam tanah sehingga terjadi peningkatan kation-kation basa dalam tanah. Terjadinya penurunan Al-dd dan Kejenuhan Al setelah diinkubasi disebabkan oleh Si dapat bereaksi dengan Al di dalam tanah. Dengan pemberian abu sekam sebagai sumber $\mathrm{Si}$ ke dalam tanah akan menyebabkan Al kurang larut, karena terjadinya ikatan antara anion silikat dengan Al (Silva, 1971). Terjadinya penurunan Aldd dan kejenuhan $\mathrm{Al}$ setelah inkubasi disebabkan oleh abu sekam sebagai sumber Si dapat bereaksi dengan $\mathrm{Al}$ dalam tanah.

\section{Pertumbuhan Tanaman}

Parameter pertumbuhan yang diamati disi yaitu tingi tanaman, jumlah anakan produktif, dan bobot kering gabah (Tabel 3). Dari analisis sidik ragam ternyata pengaruh pemberian abu sekam sebagai sumber silikat ( $\mathrm{Si}$ ) terhadap tinggi tanaman tidak memperlihatkan perbedaan yang nyata.

Dari Tabel 3 dapat dikatakan bahwa pemberian abu sekam sebagai sumber silika terhadap parameter tinggi tanaman tidak berbeda nyata. Parameter tinggi tanaman tidak mencerminkan pengaruh perlakuan yang sebenarnya terhadap pertumbuhan tanaman. Hal ini dapat dilihat dari tinggi tanaman yang sama antar perlakuan, namun jumlah anakan menunjukkan jumlah yang nyata. Dari pengamatan langsung didapat bahwa pertumbuhan tanpa perlakuan lebih jelek dibandingkan perlakuan yang lain. 
Tabel 3. Pengaruh pemberian abu sekam sebagai sumber Si terhadap tinggi tanaman, jumlah anakan produktif, dan bobot kering gabah.

\begin{tabular}{cccc}
\hline Perlakuan & $\begin{array}{c}\text { Tinggi tanaman } \\
(\mathrm{cm})\end{array}$ & $\begin{array}{c}\text { Anakan } \\
\text { (batang) }\end{array}$ & $\begin{array}{c}\text { Berat kering } \\
\text { gabah }(\mathrm{g})\end{array}$ \\
\hline $\begin{array}{c}\text { Tanpa abu } \\
\text { sekam }\end{array}$ & $107,0 \mathrm{a}$ & $13,0 \mathrm{a}$ & $26,0 \mathrm{a}$ \\
$1400 \mathrm{~kg} / \mathrm{ha}$ & $106,4 \mathrm{a}$ & $17,0 \mathrm{~b}$ & $34,4 \mathrm{~b}$ \\
$2800 \mathrm{~kg} / \mathrm{ha}$ & $106,5 \mathrm{a}$ & $22,0 \mathrm{c}$ & $47,1 \mathrm{c}$ \\
$5600 \mathrm{~kg} / \mathrm{ha}$ & $106,6 \mathrm{a}$ & $23,0 \mathrm{c}$ & $49,9 \mathrm{c}$ \\
\hline $\mathrm{KK}(\%)$ & 0,15 & 2,64 & 4,14 \\
\hline
\end{tabular}

Angka-angka dalam kolom yang sama yang diikuti oleh huruf kecil yang sama berbeda tidak nyata pada taraf $5 \%$ menurut DNMRT

Dari hasil pengamatan terhadap jumlah anakan produktif memperlihatkan perbedaan yang nyata untuk masing-masing perlakuan. Jumlah anakan dapat dijadikan faktor pertumbuhan tanaman, Harahap (1997) melaporkan peranan unsur hara sangat nyata pada setiap fase pertumbuhan, pemberian pupuk $P$ baik dalam bentuk organik maupun anorganik pada tanaman padi dipakai untuk pembentukan daun, tunas dan anakan, ini terjadi pada pertumbuhan vegetatif.

Pada Tabel 3 juga terlihat bahwa pemberian abu sekam berbeda nyata terhadap perlakuan tanpa abu sekam. Jika dibandingkan dengan deskripsi hasilnya akan terus meningkat dengan meningkatnya taraf abu sekam yang diberikan, hasilnya melebihi dari deskripsi yang dikeluarkan.

Peningkatan berat kering gabah disebabkan adanya sumbangan unsur hara dari abu sekam secara tidak langsung meningkatkan ketersediaaan unsur hara di tanah, terutama unsur $\mathrm{P}, \mathrm{Si}, \mathrm{K}, \mathrm{Ca}$, dan $\mathrm{Mg}$ yang berguna bagi pertumbuhan pada fase generatif, seperti pembentukan biji dan proses pematangannya. Sesuai dengan pendapat Nyakpa et al (1985), bahwa Ca sangat mendorong produksi tanaman padipadian dan biji-bijian, demikian juga halnya dengan $\mathrm{Mg}$ yang memegang peranan penting dalam meningkatkan produksi tanaman karena $\mathrm{Mg}$ merupakan salah satu penyusun klorofil dan pembentukan biji. Unsur $P$ berperan dalam pembentukan bunga dan biji serta kualitas hasil tanaman. Unsur Si walaupun bukan unsure penting tetapi dapat meningkatkan produksi tanaman padi

Serapan P dan Si Tanaman (daun + batang)

Serapan P (batang + daun) tanaman sesudah di analisis secara statistik dan dilanjutkan dengan uji lanjut DNMRT pada taraf $5 \%$ dapat dilihat pada Tabel 4.

Meningkatnya serapan $\mathrm{P}$ tanaman disebabkan terjadinya peningkatan $\mathrm{P}$ tersedia karena pemberian abu sekam sebagai sumber Si. Selain itu pemberian abu sekam dapat meningkatkan Ca-dd dan K-dd serta menurunkan Al-dd, akibatnya tanaman dapat tumbuh dengan baik karena efek meracun dari Al dapat berkurang. Hakim (1982) menyatakan bahwa serapan P oleh tanaman meningkat sejalan dengan meningkatnya kelarutan $\mathrm{P}$ dan menurunnya kandungan Al-dd tanah. Serapan P oleh tanaman akan terganggu apabila Al-dd di dalam tanah tinggi.

Madappa dan Dana 1968 (cit Hakim, 1982) melaporkan bahwa serapan $P$ tanaman dapat berkurang karena adanya Al. $\mathrm{P}$ diendapkan oleh $\mathrm{Al}$ di dalam akar tanaman, sehingga metabolisme $\mathrm{P}$ ke bagian atas tanaman terhambat.

Dari Tabel 4 dapat diketahui bahwa terdapat pengaruh-pemberian takaran abu sekam terhadap Si tanaman 
Tabel 4. Pengaruh pemberian abu sekam sebagai sumber Si terhadap serapan P tanaman.

\begin{tabular}{ccc} 
Perlakuan & Serapan P tanaman & Serapan Si tanaman \\
\hline Tanpa abu sekam & $85,45 \mathrm{a}$ & $1,72 \mathrm{c}$ \\
$1400 \mathrm{~kg} / \mathrm{ha}$ & $100,98 \mathrm{a}$ & $3,44 \mathrm{~b}$ \\
$2800 \mathrm{~kg} / \mathrm{ha}$ & $140,85 \mathrm{bc}$ & $4,52 \mathrm{a}$ \\
$5600 \mathrm{~kg} / \mathrm{ha}$ & $129,12 \mathrm{c}$ & $4,34 \mathrm{a}$ \\
\hline $\mathrm{KK}(\%)$ & 1,85 & 3,77 \\
\hline
\end{tabular}

Angka-angka dalam kolom yang sama yang diikuti oleh huruf kecil yang sama berbeda tidak nyata pada taraf $5 \%$ menurut DNMRT

(daun + batang). Pemberian takaran abu sekam pada tanpa perlakuan dan $1400 \mathrm{~kg} / \mathrm{ha}$ $(5,6 \mathrm{~g} / \mathrm{pot})$ terlihat memberikan pengaruh yang nyata terhadap peningkatan $\mathrm{Si}$ tanaman (daun + batang). Pengaruh yang tidak nyata terlihat pada pemberian 2800 $\mathrm{kg} / \mathrm{ha}(11,2 \mathrm{~g} / \mathrm{pot})$ dan $5600 \mathrm{~kg} / \mathrm{ha}(22,4$ $\mathrm{g} / \mathrm{pot})$.

Pemberian takaran abu sekam sebanyak $1400 \mathrm{~kg} / \mathrm{ha}(5,6 \mathrm{~g} / \mathrm{pot})$ sudah mampu memberikan pengaruh yang nyata terhadap Si tanaman (daun + batang) bila dibandingkan dengan tanpa pemberian abu sekam, dimana peningkatan $\mathrm{Si}$ tanaman (daun + batang) sebesar 1,72 g/pot. Selanjutnya apabila takaran abu sekam dinaikkan menjadi $2800 \mathrm{~kg} / \mathrm{ha}(11,2 \mathrm{~g} / \mathrm{pot})$ dan $5600 \mathrm{~kg} / \mathrm{ha}(22,4 \mathrm{~g} / \mathrm{pot})$ belum mampu meningkatkan Si tanaman (daun + batang) yaitu sebesar 2,8 g/pot dan 2,62 g/pot dan berbeda nyata dengan perlakuan tanpa abu sekam dan pada perlakuan $1400 \mathrm{~kg} / \mathrm{ha}(11,2$ $\mathrm{g} / \mathrm{pot})$. Walaupun demikian, dapat dilihat bahwa Si tanaman (daun + batang) tertinggi diperoleh dengan pemberian abu sekam sebanyak $2800 \mathrm{~kg} / \mathrm{ha} \quad(11,2 \mathrm{~g} / \mathrm{pot})$ yaitu sebesar 4,52 g/pot.

\section{KESIMPULAN}

Dari hasil penelitian, pengaruh pemberian abu sekam sebagai sumber silika (Si) bagi pertumbuhan dan produksi tanaman padi dapat disimpulkan bahwa :

1. Pemberian abu sekam sebanyak $2800 \mathrm{~kg} / \mathrm{ha}$ mampu meningkatkan P-tersedia tanah sebesar 5,90 ppm,
Si-tersedia tanah sebesar 39,73 dan meningkatkan-dd tanah 0,08 me/100 g, Ca-dd tanah 0,2 me/100 g, Mg-dd tanah 0,01 me/100 g serta menurunkan Al-dd tanah 1,43 me/100 gdan kejenuhan Al 13,04 \% dibandingkan dengan pemberian perlakuan tanpa abu sekam.

2. Pemberian abu sekam meningkatkan jumlah anakan produktif dan produksi tanaman padi. Perlakuan optimum diperoleh pada pemberian abu sekam sebanyak $2800 \mathrm{~kg} / \mathrm{ha}$ di mana mampu meningkatkan serapan $\mathrm{P}$ dan $\mathrm{Si}$ (daun + batang) sebesar $0,56 \mathrm{~g} \mathrm{P} /$ pot dan 2,72 g Si/pot, berat kering gabah padi sebesar 21,08 g/pot $(* 1,08 \%)$ dibandingkan tanpa pemberian abu sekam.

\section{DAFTAR PUSTAKA}

Azhari. 1992. Pemberian abu sekam dan pupuk TSP pada lahan sawah serta pengaruhnya terhadap fosfor tersedia dan produksi padi sawah. Skripsi Fakultas Pertanian Universitas Andalas. Padang. 53 halaman

Berina, O. 1989. Pengaruh pemberian abu sekam terhadap sifat kimia tanah dan hasil tanaman kedelai pada tanah podzolik. Tesis Fakultas Pertanian Universitas Andalas Padang. Padang 65 halaman 
Darmawan. 2005. Uji penggunaan abu sekam dan abu batu bara sebagai sumber silica bagi tanaman padi, suatu tantangan dan harapan di masa depan. Fakultas Pertanian Universitas Andalas. Padang. 7 halaman

Hakim, N. 1982. Pengaruh pemberian pupuk hiijau dan kapur pada podzolik merah kuning terhadap ketersediaan $\mathrm{P}$ dan produksi jagung. Disertai Doktor. Fakultas Pasca Sarjana IPB. Bogor. 272 halaman

Hakim, N. , M. Y. Nyakpa, A. M. Lubis, S. G. Nugroho, A. Diha, G. B. Hong dan H. H. Bailey. 1986. Dasardasar Ilmu Tanah. Universitas Lampung. 488 halaman

Hardjowigeno, S. 2003. Ilmu Tanah. Akademika Pressindo. Jakarta. 286 halaman

Ismunadji, M. , G. Soepardi, M. Satari dam M. Mulyadi. 1989.

Kalium dan tanaman pangan, problem dan prospek. LP3, Bogor. Bogor. 162 halaman

Kasli. 1987. Pengaruh pemberian pupuk kalium terhadap perkembangan bintil akar, pertumbuhan dan produksi beberpa varietas kedelai. Departemen Pendidikan dan Kebudayaan. Pusat Penelitian Universitas Andalas Padang. Padanag. 44 halaman

Salehuddin. 1990. Pengaruh pemberian sekam padi dan fosfor terhadap kandungan hara dan produksi kedelai pada tanah podzolik merah kuning. Fakultass Pasca Sarjana Institut Pertanian Bogor. Bogor. 83 halaman

Sanchez, P. A. 1992. Sifat dan Pengelolaan Tanah Tropika jilid 2. Terjemahan Amir Hamzah dari Properties and Management of Soil in the Tropics. ITB. Bandung. 397 halaman

Silva., J. A. 1971. Possible mechanism for crop respons to silicate application. Proc. Int $1: 805-814$

Soepardi, G. 1983. Sifat dan Ciri Tanah. Institut Pertanian Bogor. Bogor. 591 halaman

Taher dan Abbas. 1990. Perpadian dunia, transmigrasi dan pengelolaan sawah bukaan baru di Indonesia. Dalam Prosiding : Pengelolaan sawah bukaan baru menunjang swasembada pangan dan program transmigrasi. Universitas Ekasakti dab BPTP Sukarami. Halaman 121 $-147$

Winarno, F. G. 1985. Penanganan Limbah Tanaman Pangan. Monografi pertama limbah pertanian. Kantor Mentri Muda urusan Peningkatan Produksi Pangan. Halaman 11-17

Wiralaga, A. Y. A. , A. M. Lubis, M. A. Pulung, N. Hakim dan M. Y. Nyakpa. 1988. Kimia Tanah. Badan kerja sama ilmu tanah. BKS_PTN/USAID (University of Kentucky) WUEA Project. 364 halaman 